\title{
Case Report \\ Development of Nephrotic Syndrome after Administration of Sorafenib in a Case of Metastatic Renal Cell Carcinoma
}

\author{
Yumiko Okuno, Haruki Kume, Chihiro Hosoda, and Yukio Homma \\ Department of Urology, The University of Tokyo Hospital, Tokyo 113-8655, Japan \\ Correspondence should be addressed to Haruki Kume, kumeh-uro@h.u-tokyo.ac.jp
}

Received 7 July 2011; Accepted 9 August 2011

Academic Editor: W. Zidek

Copyright ( $) 2011$ Yumiko Okuno et al. This is an open access article distributed under the Creative Commons Attribution License, which permits unrestricted use, distribution, and reproduction in any medium, provided the original work is properly cited.

\begin{abstract}
Nephrotic syndrome, after administration of tyrosine kinase inhibitors, is uncommon and not well known. A 62-year-old male, who had experienced a left nephrectomy due to a traffic accident 38 years ago, underwent a partial nephrectomy for right renal cell carcinoma (RCC). Histologically, the tumor was a clear cell RCC. Two years later abdominal CT revealed para-aortic lymph node metastasis. During these two years, serum creatinine had increased from $2.0 \mathrm{mg} / \mathrm{dL}$ to $2.9 \mathrm{mg} / \mathrm{dL}$ along with the appearance of proteinuria. After only a week of sorafenib, $400 \mathrm{mg} /$ day, fever developed and sorafenib was stopped. Although normotensive, his serum creatinine increased to $3.83 \mathrm{mg} / \mathrm{dL}$ and serum albumin decreased from $1.8 \mathrm{~g} / \mathrm{L}$ to $1.0 \mathrm{~g} / \mathrm{L}$. Proteinuria also worsened to $27.5 \mathrm{~g} /$ day. He became edematous, and ascites and cardiac effusions also appeared. He was diagnosed with nephrotic syndrome. A retrospective review of the histology of the partial nephrectomy revealed no change in the glomeruli.
\end{abstract}

\section{Introduction}

Recently, vascular endothelial growth factor (VEGF) receptor blockers have been commonly used for treating advanced renal cell carcinoma (RCC). Although renal dysfunction caused by these inhibitors is uncommon, it is important for advanced RCC because many RCC cases have chronic kidney disease $[1,2]$. However, this uncommon adverse effect has not been well documented.

\section{Case Report}

A 62-year-old male, who had been subjected to a left nephrectomy due to a traffic accident at the age of 24 , was admitted for treatment of a right renal cell carcinoma, which measured $11 \mathrm{~cm}$ in diameter. Partial nephrectomy was performed that included 25 minutes of warm ischemic time. Histologically, the tumor was a clear cell RCC without perinephric fat or microvascular invasions.

Two years after the surgery, abdominal CT revealed paraaortic lymph node metastasis, $2.5 \mathrm{~cm}$ in diameter, which was confirmed histologically by CT-guided biopsy. During the two years after the partial nephrectomy, serum creatinine had increased gradually from $2.0 \mathrm{mg} / \mathrm{dL}$ to $2.9 \mathrm{mg} / \mathrm{dL}$ together with the appearance of proteinuria.

Sorafenib, $400 \mathrm{mg} / \mathrm{day}$, was started but after only a week of administration a fever developed and sorafenib was stopped. Although he was normotensive after the cessation of sorafenib, serum creatinine increased to $3.83 \mathrm{mg} / \mathrm{dL}$ and serum albumin decreased from $1.8 \mathrm{~g} / \mathrm{L}$ to $1.0 \mathrm{~g} / \mathrm{L}$. Proteinuria also worsened; the amount of urinary protein was $27.5 \mathrm{~g} /$ day. He became edematous and his body weight increased from $53.5 \mathrm{~kg}$ to $57.6 \mathrm{~kg}$. Ascites and cardiac effusions also appeared.

He was diagnosed with nephrotic syndrome. With sodium restriction, supplementation of albumin, and administration of diuretics, his edema, ascites, and cardiac effusions were improved. The amount of urinary protein was also reduced to $9.4 \mathrm{~g} /$ day.

Renal biopsy was not performed because of the possible complications that could progress to deterioration of renal function. A retrospective review of the histology of the 


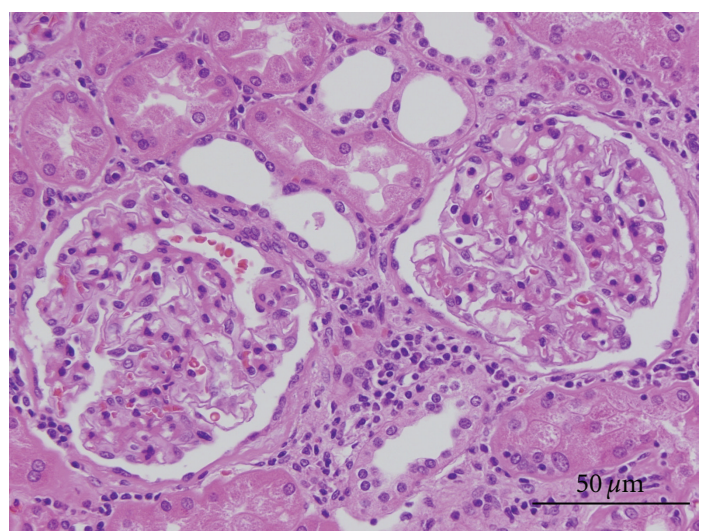

Figure 1

partial nephrectomy revealed no change in the glomeruli (Figure 1).

\section{Discussion}

Ablation of the kidney results in proteinuria, hypertension, progressive renal failure, and advanced glomerulosclerosis in animal models [1]. Also, clinically in chronic kidney disease, glomerular filtration rate under $60 \mathrm{~mL} / \mathrm{min}$ is known to develop within three years in two thirds of cases that underwent radical nephrectomy [2]. As this case involved a partial nephrectomy for RCC in a solitary kidney, only a small volume of parenchyma remained, which could cause progression of renal dysfunction after the surgery.

Nephrotic syndrome induced by tyrosine kinase inhibitors (TKIs) such as sorafenib and sunitinib has been reported only in several cases [3-9], although it seems more common in cases treated by bevacizumab, a humanized monoclonal antibody neutralizing VEGF. However, the etiology is not fully understood [10]. VEGF, produced by podocytes, activates VEGF receptor 2 on glomerular capillary endothelial cells. Its inhibition may cause a loss of endothelial fenestrations and reduced proliferation of endothelial cells. Thrombotic microangiopathy and hypertension induced by anti-VEGF therapy may play a role [10].

Before administration of sorafenib, this case was already in renal insufficiency with low serum albumin and proteinuria, although it did not meet the diagnostic criteria of nephrotic syndrome. However, cases without proteinuria have been reported to develop nephrotic syndrome after TKI treatment [3-7]. Although the risk factors for renal dysfunction after anti-VEGF therapy remain unknown, this infrequent adverse effect cannot be ignored.

\section{References}

[1] W. C. Huang, A. S. Levey, A. M. Serio et al., "Chronic kidney disease after nephrectomy in patients with renal cortical tumours: a retrospective cohort study," The Lancet Oncology, vol. 7, no. 9, pp. 735-740, 2006.

[2] J. McKiernan, R. Simmons, J. Katz, and P. Russo, "Natural history of chronic renal insufficiency after partial and radical nephrectomy," Urology, vol. 59, no. 6, pp. 816-820, 2002.
[3] E. J. Rolleman, J. Weening, and M. G. H. Betjes, "Acute nephritic syndrome after anti-VEGF therapy for renal cell carcinoma," Nephrology Dialysis Transplantation, vol. 24, no. 6, pp. 2002-2003, 2009.

[4] E. N. Overkleeft, R. Goldschmeding, F. van Reekum, E. E. Voest, and H. M. Verheul, "Nephrotic syndrome caused by the angiogenesis inhibitor sorafenib," Annals of Oncology, vol. 21, no. 1, pp. 184-185, 2010.

[5] S. K. Winn, S. Ellis, P. Savage, S. Sampson, and J. E. Marsh, "Biopsy-proven acute interstitial nephritis associated with the tyrosine kinase inhibitor sunitinib: a class effect?" Nephrology Dialysis Transplantation, vol. 24, no. 2, pp. 673-675, 2009.

[6] T. V. Patel, J. A. Morgan, G. D. Demetri et al., "A preeclampsialike syndrome characterized by reversible hypertension and proteinuria induced by the multitargeted kinase inhibitors sunitinib and sorafenib," Journal of the National Cancer Institute, vol. 100, no. 4, pp. 282-284, 2008.

[7] Y. S. Chen, C. L. Chen, and J. S. Wang, "Nephrotic syndrome and acute renal failure apparently induced by sunitinib," Case Reports in Oncology, vol. 2, pp. 172-176, 2009.

[8] I. J. Jonkers and M. van Buren, "Nephrotic-range proteinuria in a patient with a renal allograft treated with sorafenib for metastatic renal-cell carcinoma," Clinical and Experimental Nephrology, vol. 13, no. 4, pp. 397-401, 2009.

[9] O. Costero, M. L. Picazo, P. Zamora, S. Romero, J. MartinezAra, and R. Selgas, "Inhibition of tyrosine kinases by sunitinib associated with focal segmental glomerulosclerosis lesion in addition to thrombotic microangiopathy," Nephrology Dialysis Transplantation, vol. 25, no. 3, pp. 1001-1003, 2010.

[10] S. Wu, C. Kim, L. Baer, and X. Zhu, "Bevacizumab increases risk for severe proteinuria in cancer patients," Journal of the American Society of Nephrology, vol. 21, no. 8, pp. 1381-1389, 2010. 


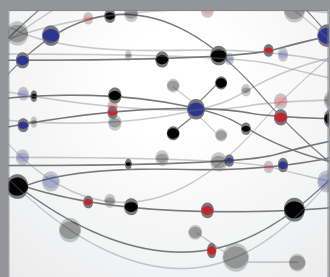

The Scientific World Journal
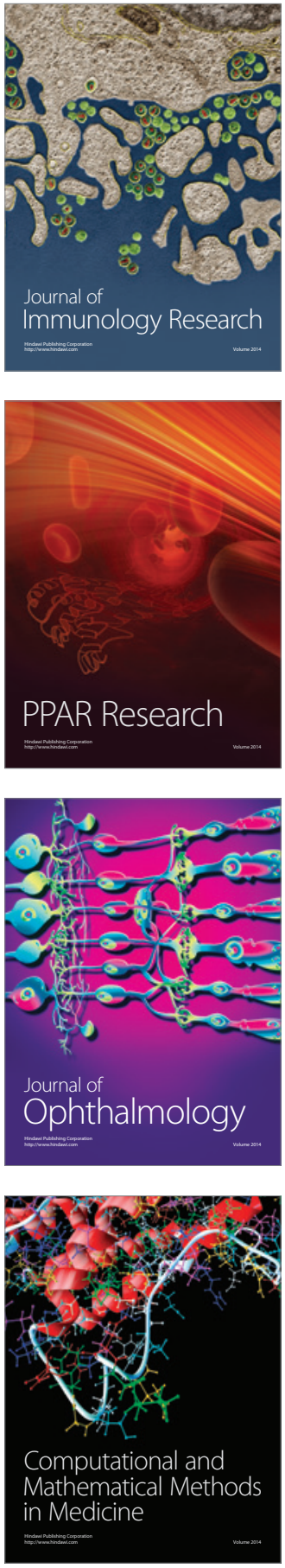

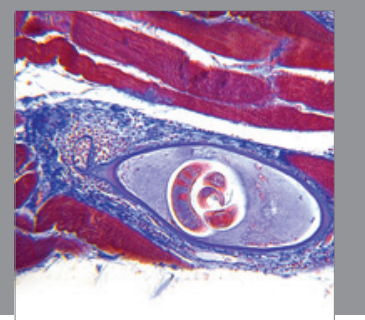

Gastroenterology

Research and Practice
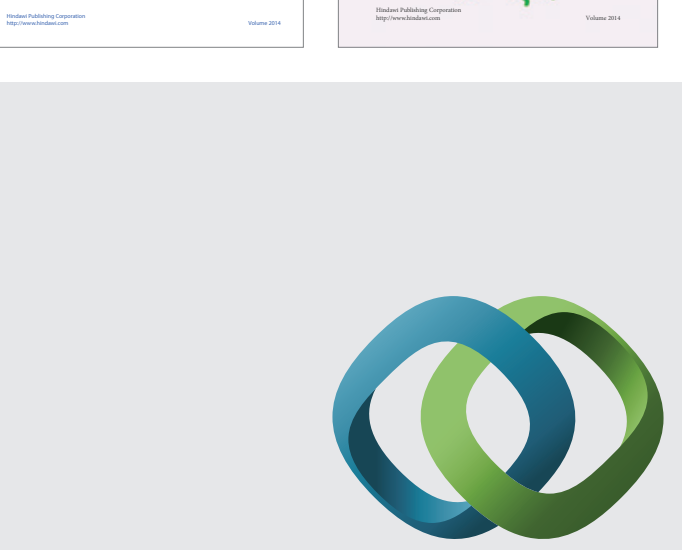

\section{Hindawi}

Submit your manuscripts at

http://www.hindawi.com
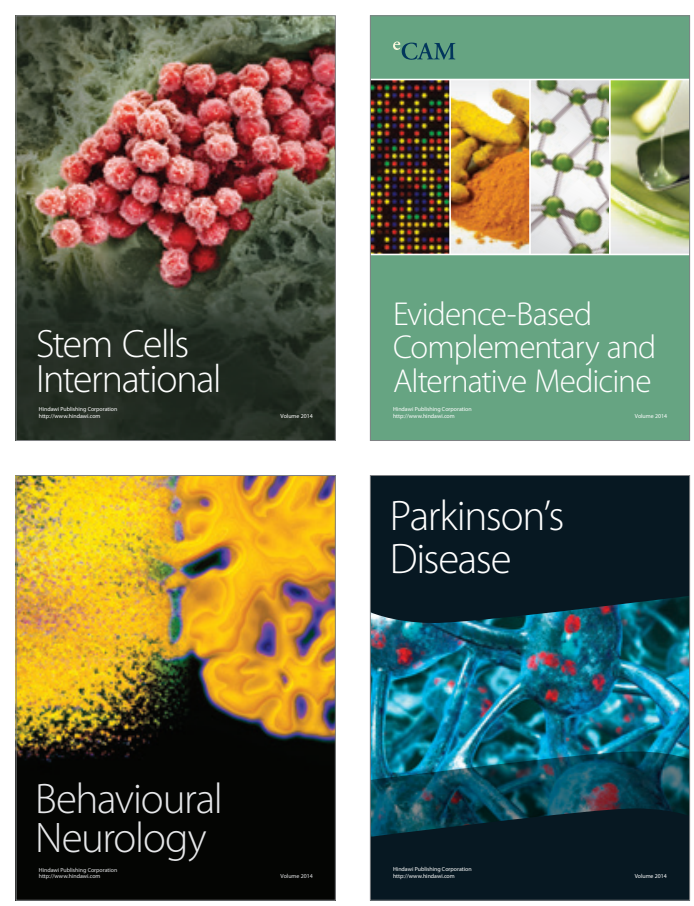

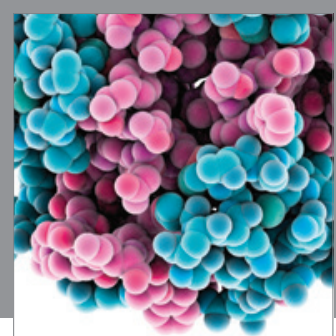

Journal of
Diabetes Research

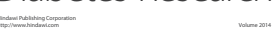

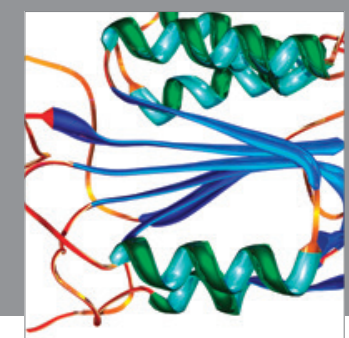

Disease Markers
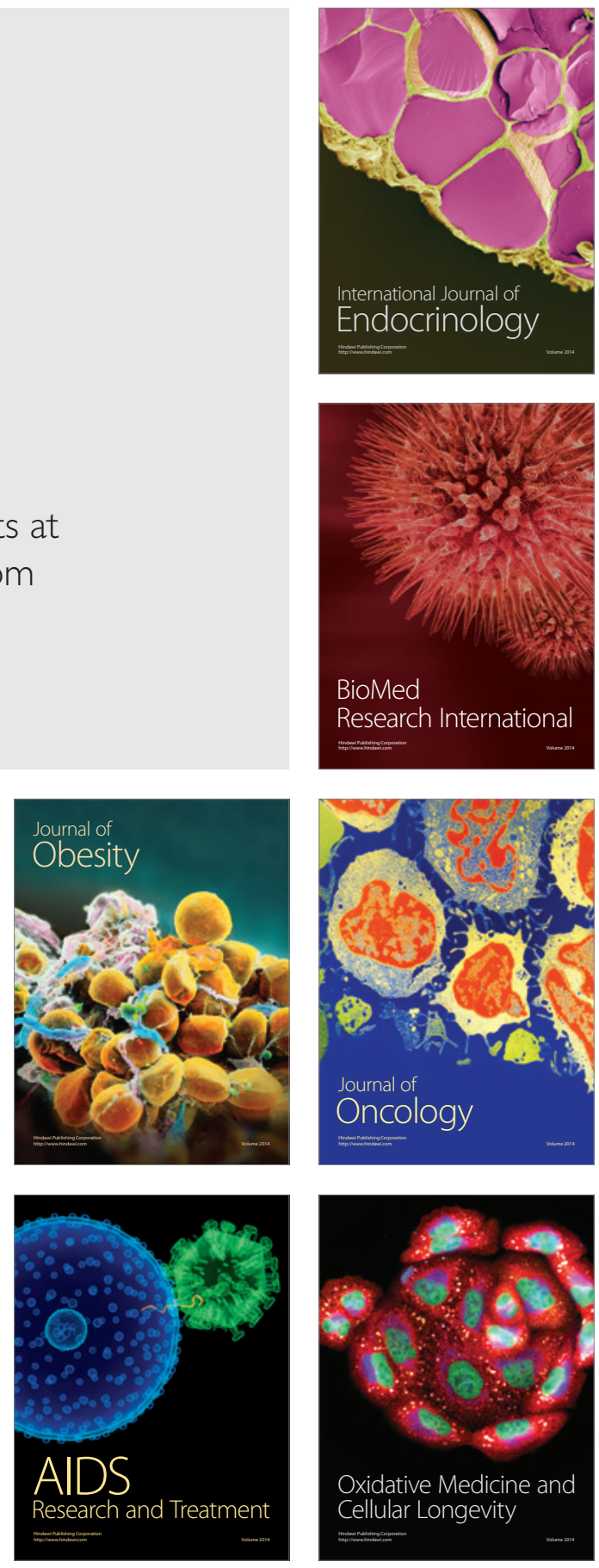